\title{
Oocyte growth in the immature rat
}

\author{
E. Arendsen de Wolff-Exalto and A. C. Groen-Klevant \\ Department of Anatomy, Erasmus University Rotterdam, Rotterdam, The Netherlands
}

\begin{abstract}
Summary. Growth rates of oocytes in the ovary cannot be measured directly. However, oocyte growth can be determined by relating oocyte diameter to the time the enclosing follicle has been growing, calculated from kinetic studies of granulosa cell doubling time. For the ovaries of immature rats aged 16 and 28 days, oocyte diameter plotted against time gave straight and parallel lines, showing that the diameter is positively and linearly related to time and that oocytes grow at the same rate at both ages. However, during earliest developmental stages (type $3 \mathrm{a}$ follicles with 10-20 granulosa cells) the growth rates differed, being faster at 16 days and slower at 28 days than at later stages.
\end{abstract}

\section{Introduction}

Follicle development between birth and first ovulation has been investigated by studying granulosa cell kinetics in ovaries of mice (Pedersen, 1969) and rats (Hage, Groen-Klevant \& Welschen, 1978), and in this way the growth rates of different types of follicles (as defined by Pedersen \& Peters, 1968) have been established.

At present a method for measuring growth rates of oocytes directly is not available. Oocyte growth has previously been studied by relating oocyte diameter to the diameter of the enclosing follicle. Such measurements have generally led to the view that after having started its growth, the oocyte grows rapidly at first but almost stops growing when near to its maximum size, whereas the follicle continues to grow. Thus, a biphasic pattern has been found in the mouse (Brambell, 1928; Moore \& Lintern-Moore, 1974; Lintern-Moore \& Pantelouris, 1975, 1976), rat (Mandl \& Zuckerman, 1952; Brambell, 1956) and all other mammals studied (Brambell, 1956). However, since it has been demonstrated that large follicles grow faster than medium ones (Pedersen, 1969; Hage et al., 1978), the question arises whether the biphasic pattern of the relationship between oocyte diameter and follicle diameter is caused by changes in follicle growth, oocyte growth, or both. It seemed possible to determine growth rates of oocytes indirectly, using data on growth rates of follicles. The following study was therefore undertaken to establish the time pattern of oocyte growth in immature rats and to answer the question outlined above.

\section{Principles}

Since oocytes and follicles grow simultaneously, the time it takes a follicle to reach a certain size is also the time during which the enclosed oocyte has been growing. The times that follicles take to pass through successive stages of development have been calculated for the immature rat (Hage et al., 1978) and it is therefore possible to determine the time pattern of oocyte growth by relating oocyte diameters to these times. Every type of follicle can be defined by a minimal and a 
maximal number of granulosa cells and these cell numbers limit what has been called compartment (Pedersen, 1969) through which a growing follicle passes. The time taken by follicles to move through a compartment is called the transit time and such times have been determined for follicles of types $3 \mathrm{~b}$ to 7 (Hage et al., 1978). The number of granulosa cells can therefore be used to determine the time that has elapsed since the follicle acquired the minimal number of granulosa cells of a specific type of follicle, i.e. after it entered the compartment concerned. In this way the number of granulosa cells permits calculation of the time a follicle, and therefore the enclosed oocyte, has been growing.

\section{Materials and Methods}

Oocytes and follicles were studied in one ovary each of 4 16- and 4 28-day-old Wistar rats of the R-Amsterdam substrain. The same ovaries had been used previously to establish follicle growth rates (for full details see Hage et al., 1978). To compare the data on oocyte growth in rats obtained in the present study with those of previous studies, the relation between sizes of oocytes and follicles was first established. As a standard for follicle growth the number of granulosa cells in the largest cross-section was preferred to follicle diameter, since the number of cells was also used for determining the time a follicle had been growing.

In total over 250 follicles of type $3 \mathrm{~b}$ up to type 7 (follicles with $20-600$ granulosa cells in the largest cross-section) were studied. The numbers of granulosa cells and the diameters of the enclosed oocytes were determined in the cross-section showing the oocyte nucleolus.

The transit time of type 3 a follicles was established in autoradiographs of 16- and 28-day-old rat ovaries prepared by the method of Pedersen (1969). Rats were injected with $\left[{ }^{3} \mathrm{H}\right]$ thymidine and killed after time intervals ranging from 1 to $22 \mathrm{~h}$. Ovaries were fixed in Bouin's fluid, serially sectioned at $5 \mu \mathrm{m}$, coated with Kodak nuclear emulsion $\mathrm{K} 2$, exposed for $7-10$ days at $4^{\circ} \mathrm{C}$, developed and stained with haematoxylin and eosin. The percentages of labelled cells and of labelled mitotic figures in follicles were recorded (for further details see Hage et al., 1978). No labelled cells were present in follicles with less than 10 granulosa cells in the largest cross-section. Hence the study of oncyte growth was limited to oocytes in follicles with more than 10 granulosa cells (Table 1). For follicles of types $3 \mathrm{~b}-7$, transit times from the study of Hage et al. (1978) and obtained with the method outlined above for type $3 \mathrm{a}$ follicles, were used.

Table 1. Values for the labelling index (mean \pm s.e.m.) and various times (mean \pm s.d.) during the growth of type 3a rat follicles* with 10-20 granulosa cells in the largest cross-section

\begin{tabular}{cccccc}
\hline $\begin{array}{c}\text { Age } \\
\text { (days) }\end{array}$ & $\begin{array}{c}\text { Labelling } \\
\text { index } \\
(\%)\end{array}$ & $\begin{array}{c}\text { Time between injection } \\
\text { and 50\% labelling } \\
\text { of mitotic } \\
\text { figures (h) }\end{array}$ & $\begin{array}{c}\text { Duration } \\
\text { of S } \\
\text { phase } \\
\text { (h) }\end{array}$ & $\begin{array}{c}\text { Doubling } \\
\text { time } \\
(\mathrm{h})\end{array}$ & $\begin{array}{c}\text { Transit } \\
\text { time } \\
(\mathrm{h})\end{array}$ \\
\hline 16 & $9.7 \pm 0.3$ & $2.3 \pm 0.3$ & $10.2 \pm 0.7$ & 78.5 & 133 \\
28 & $7.2 \pm 0.3$ & $2.5 \pm 0.6$ & $12.6 \pm 1.2$ & 128.0 & 218 \\
\hline
\end{tabular}

* Four ovaries at each age were studied.

\section{Results}

When oocyte diameter was related to the numbers of granulosa cells of the enclosing follicle, a biphasic pattern was obtained. The point of intersection of the two lines was within the range of type 5a follicles ( \pm 125 cells; see Text-fig. 1). When oocyte diameters were plotted against time, however, straight lines appeared for the rats of both ages and these lines were parallel (Text-fig. 2; Table 2). 


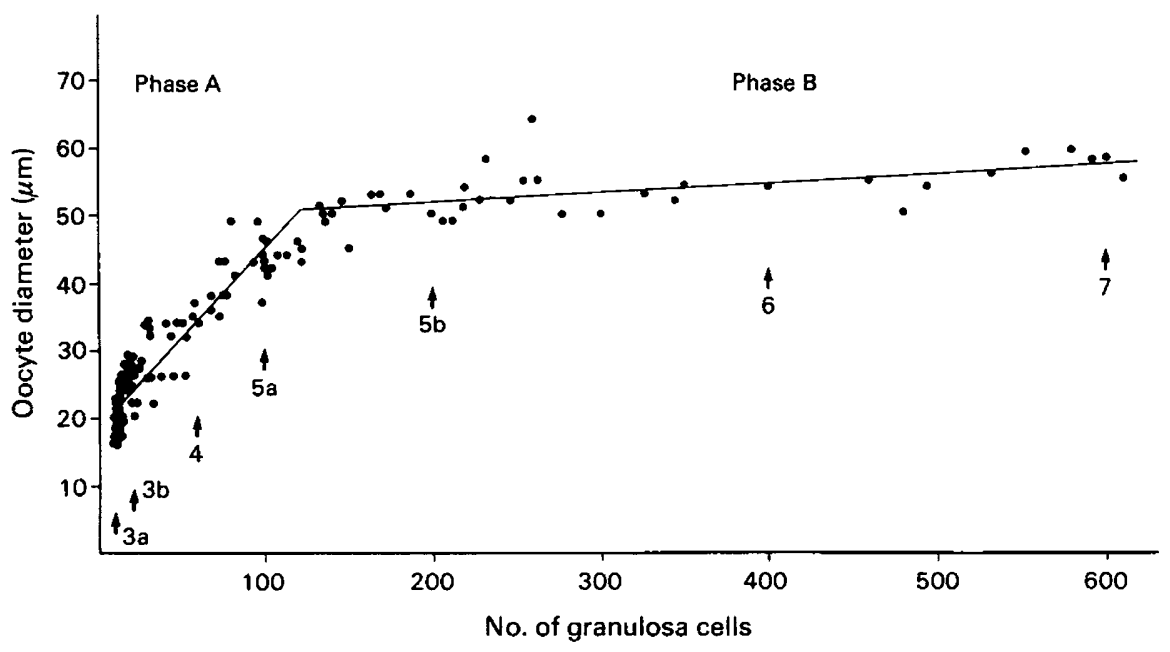

Text-fig. 1. Relation between oocyte diameter and number of granulosa cells in the largest crosssection of the enclosing follicle in 4 ovaries from 28-day-old rats. The corresponding mean \pm s.e.m. values for $\mathrm{a}$ and $\mathrm{b}$ in the regression equation $y=\mathrm{b} x+\mathrm{a}$ were $20.89 \pm 0.84$ and $0.21 \pm$ 0.01 in Phase $\mathrm{A}(r=0.92 \pm 0.01)$ and 48.96 \pm 2.04 and $0.014 \pm 0.003$ in Phase $\mathrm{B}(r=0.52$ \pm 0.15 ). The start of each follicle category (Pedersen \& Peters, 1968) is indicated.

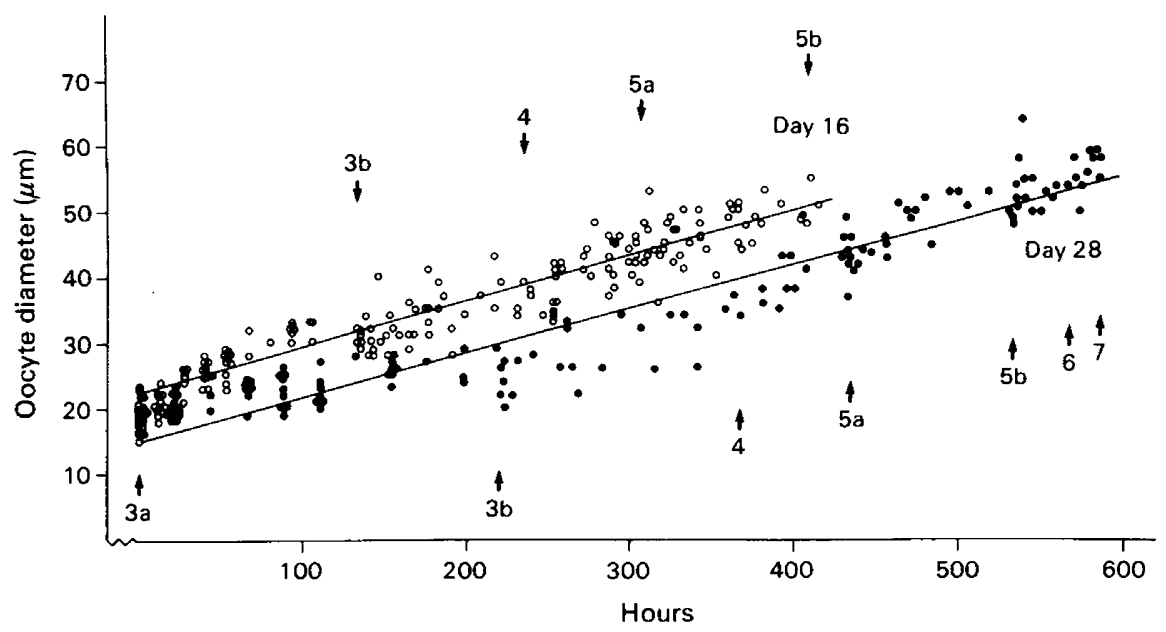

Text-fig. 2. Relation between rat oocyte diameter and time (derived from growth of follicles) at Days $16(0)$ and $28(0)$. The coefficients of the linear regressions are given in Table 2 . The start of each follicle category (Pedersen \& Peters, 1968) is indicated.

Direct measurements of oocyte diameters revealed that follicles with 10 granulosa cells in the largest cross-section enclosed oocytes of the same size at both ages, but in type $3 \mathrm{a}$ follicles with $>10$ cells, oocyte diameter was significantly smaller on Day 28 than on Day 16 (Table 3). Comparison of the oocyte diameters of these type $3 \mathrm{a}$ follicles measured directly with those derived from the regression lines (Text-fig. 2) showed that at Day 16 the diameter measured directly was less than that calculated, while at Day 28 the direct measurements yielded larger diameters. These differences disappeared by 27 and $87 \mathrm{~h}$ at Days 16 and 28 respectively (Table 3). 
Table 2. Coefficients of linear regression $(y=b x+a)$ relating oocyte diameter, $y(\mu \mathrm{m})$, to time, $x(\mathrm{~h})$, in ovaries of 16- and 28-day-old rats

\begin{tabular}{cclll}
\hline $\begin{array}{c}\text { Age } \\
\text { (days) }\end{array}$ & Rat & \multicolumn{1}{c}{ a } & \multicolumn{1}{c}{ b } & \multicolumn{1}{c}{$r$} \\
\hline \multirow{4}{*}{16} & 1 & 24.39 & 0.06 & 0.95 \\
& 2 & 22.05 & 0.07 & 0.93 \\
& 3 & 21.26 & 0.07 & 0.97 \\
& 4 & 21.96 & 0.07 & 0.93 \\
& Mean \pm s.e.m. & $22.54 \pm 0.68$ & $0.07 \pm 0.00$ & $0.94 \pm 0.01$ \\
\hline \multirow{3}{*}{28} & 11 & 13.86 & 0.07 & 0.94 \\
& 12 & 15.07 & 0.07 & 0.92 \\
& 13 & 17.63 & 0.06 & 0.95 \\
& 14 & 13.44 & 0.07 & 0.96 \\
& Mean \pm s.e.m. & $15.10 \pm 0.94$ & $0.07 \pm 0.00$ & $0.94 \pm 0.01$ \\
\hline
\end{tabular}

Table 3. Mean oocyte diameters, calculated and measured directly, at different times (calculated from numbers of granulosa cells) after the oocytes had been surrounded by 10 granulosa cells in the largest crosssection of the enclosing follicles

\begin{tabular}{ccccc}
\hline \multirow{2}{*}{$\begin{array}{c}\text { Age } \\
\text { (days) }\end{array}$} & $\begin{array}{c}\text { No. of } \\
\text { surounding } \\
\text { cells }\end{array}$ & $\begin{array}{c}\text { Time } \\
\text { (h) }\end{array}$ & $\begin{array}{c}\text { Calculated from } \\
\text { Text-fig. } 2\end{array}$ & $\begin{array}{c}\text { Measured } \\
\text { (mean } \pm \text { s.e.m.) }\end{array}$ \\
\hline \multirow{3}{*}{16} & 10 & 0 & 22.5 & $19.3 \pm 0.5^{*}$ \\
& 11 & 13 & 23.5 & $21.0 \pm 0.5^{* \dagger}$ \\
& 12 & 27 & 24.5 & $24 \cdot 7 \pm 0.8^{\dagger}$ \\
& 13 & 40 & 25.5 & $25.6 \pm 0.1^{\dagger}$ \\
& 14 & 53 & 26.5 & $26.7 \pm 0.6^{\dagger}$ \\
\hline \multirow{3}{*}{28} & 10 & 0 & 15.0 & $17.9 \pm 0.6^{*}$ \\
& 11 & 22 & 16.5 & $19.7 \pm 0.3^{*}$ \\
& 12 & 44 & 18.0 & $22.0 \pm 0.8^{*}$ \\
& 13 & 65 & 19.5 & $22.5 \pm 0.6^{*}$ \\
& 14 & 87 & 21.0 & $22.4 \pm 0.8$ \\
\hline
\end{tabular}

* Significantly different from calculated mean, $P<0.01$ (Student's $t$ test).

$\dagger$ Significantly different from mean oocyte diameter at Day $28, P<0.05$ (Student's $t$ test).

\section{Discussion}

In our material follicles with more than 10 granulosa cells were considered to be growing, as $76 \%$ of these follicles showed labelled cells after injection of $\left[{ }^{3} \mathrm{H}\right]$ thymidine. This assumption seems in good agreement with results of Lintern-Moore \& Moore (1979), who studied the initiation of follicle and oocyte growth in the mouse. They noted low endogenous RNA polymerase activity in small oocytes, surrounded by 2-8 granulosa cells, in which activity markedly increased at the 9-cell stage. This increase was followed by an increase in oocyte size, whereas the first mitotic figures were seen in the granulosa cells of follicles with 10 granulosa cells. Linter-Moore \& Moore (1979) defined type 3a follicles as follicles with 10-20 granulosa cells, in which the oocyte has begun the process of growth. Mariana (1978) studied the relationship between oocyte area and the numbers of surrounding cells during the early stages of follicle development in the rat and noted also that the start of follicle growth coincided with an increase of oocyte size. In his study all follicles with $>15$ cells and an oocyte larger than $512 \mu \mathrm{m}^{2}$ were considered to be growing. 
If oocyte growth is approached by comparing oocyte diameter and numbers of surrounding cells (see Text-fig. 1), a phase of fast oocyte growth and a phase of apparently arrested growth can be distinguished. In full agreement with previous studies (Mandl \& Zuckerman, 1952; Brambell, 1956), the point of intersection of the two regression lines was within the range of type 5a follicles (Text-fig. 1). However, if oocyte diameter was plotted against the time the surrounding granulosa layer had been growing, straight lines appeared on both Days 16 and 28 (Text-fig. 2). Since these lines run parallel, the same positive and linear relation between growth and time exists at both ages: oocyte diameter increases by $1 \mu \mathrm{m}$ in little less than $15 \mathrm{~h}$. As the parallel lines run at some distance from each other, they indicate different values for oocyte diameters in follicles with 10 granulosa cells at Days 16 and 28 . However, the values derived from the regression lines differed from those obtained by direct measurements, which showed oocytes of the same size in follicles with 10 cells at both ages (Table 3). During early growth, however, oocytes grew faster on Day 16 than on Day 28 (Text-fig. 2) but then adjusted to the same and constant growth (Table 3 ). These differences in early growth rate became even more apparent when oocyte diameters in comparable follicles were compared at both ages. Oocytes surrounded by 11 or more cells were larger on Day 16 than on Day 28 (Table 3).

FSH is known to stimulate the multiplication rate of granulosa cells in the immature animal (Pedersen, 1970; Eshkol \& Lunenfeld, 1972; Ryle, Kent \& Boggis, 1973; Hardy, Danon, Eshkol \& Lunenfeld, 1974; Uilenbroek, Arendsen de Wolff-Exalto \& Welschen, 1976). Blood concentrations of gonadotrophins, especially of FSH, are high around Day 16 and low around Day 28 in rats (Ojeda \& Ramirez, 1972; Meijs-Roelofs, Uilenbroek, Osman \& Welschen, 1973) and so the stimulus to an increase of granulosa cells would be greater around Day 16 than around Day 28 and growth would be correspondingly faster. If the enclosed oocytes were growing at the same rate at both ages one might expect smaller oocytes in comparable type $3 \mathrm{a}$ follicles at Day 16 than at Day 28. This is in contradiction to our results (Table 3) and it is therefore tempting to assume a hormone dependency of early oocyte growth: high levels of gonadotrophins could stimulate oocyte growth directly or indirectly via the surrounding granulosa cells.

In view of our results, i.e. a continuous and constant growth of oocytes in follicles beyond the 3a-stage, the interpretation of the relation between oocyte and follicle growth should be reconsidered. The traditional biphasic pattern should be attributed to the changing growth rates of granulosa cells during follicle development. Although oocyte growth in mouse and rat may take place in different ways, the biphasic patterns relating oocyte growth with follicle growth (Brambell, 1928, 1956; Mandl \& Zuckerman, 1952; Moore \& Lintern-Moore, 1974; LinternMoore, \& Pantelouris, 1975, 1976) and the data on doubling times of granulosa cells (Pedersen, 1969; Hage et al., 1978) seem to be comparable in both species, suggesting that oocytes in mice and rats may grow in a similar way.

We thank Dr J. Moll and Dr H. M. A. Meijs-Roelofs for their very helpful criticism during the preparation of the manuscript.

\section{References}

Brambell, F.W.R. (1928) The development and morphology of the gonads of the mouse. Part III. The growth of the follicles. Proc. R. Soc. Lond. B 103, 258-263.

Brambell, F.W.R. (1956) Ovarian changes. In Marshall's Physiology of Reproduction, 3rd edn, Vol. 1, Part 1, see pp. 455-457. Ed. A. S. Parkes. Longmans Green, London.
Eshkol, A. \& Lunenfeld. B. (1972) Gonadotropic regulation of ovarian development in mice during infancy. In Gonadotrophins, pp. 335-346. Eds B. B. Saxena, C. G. Beling \& H. M. Gandy, J. Wiley \& Sons Inc., New York.

Hage, A.J., Groen-Klevant, A.C. \& Welschen, R. (1978) Follicle growth in the immature rat ovary. Acta endocr., Copenh. 88, 375-382. 
Hardy, B., Danon, D., Eshkol, A. \& Lunenfeld, B. (1974) Ultrastructural changes in the ovaries of infant mice deprived of endogenous gonadotrophins and after substitution with FSH. J. Reprod. Fert. 36, 345-352.

Lintern-Moore, S. \& Moore, G.P.M. (1979) The initiation of follicle and oocyte growth in the mouse ovary. Biol. Reprod. 20, 773-778.

Lintern-Moore, S. \& Pantelouris, E.M. (1975) Ovarian development in athymic nude mice. II. The growth of the oocyte and follicle. Mech. Ageing Develop. 4, 391-398.

Lintern-Moore, S. \& Pantelouris, E.M. (1976) Ovarian development in athymic nude mice. IV. The effect of PMSG and oestradiol on the growth of the oocyte and follicle. Mech. Ageing Develop. 5, 155-162.

Mandl, A.M. \& Zuckerman, S. (1952) The growth of the oocyte and follicle in the adult rat. J. Endocr. 8, 126132.

Mariana, J.C. (1978) Analyse biométrique de l'index de marquage des cellules folliculeuses et de la taille des ovocytes des follicules primordiaux d'ovaire de ratte adulte cyclique. Annls Biol. anim. Biochim. Biophys. 18, 1333-1342.

Meijs-Roelofs, H.M.A., Uilenbroek, J.T.J., Osman, P. \& Welschen, R. (1973) Serum levels of gonadotropins and follicular growth in prepuberal rats. In The Development and Maturation of the Ovary and its
Functions, pp. 3-11. Ed. H. Peters. Excerpta Medica, Amsterdam.

Moore, G.P.M. \& Lintern-Moore, S. (1974) A correlation between growth and RNA synthesis in the mouse oocyte. J. Reprod. Fert. 39, 163-166.

Ojeda, S.R. \& Ramirez, V.D. (1972) Plasma levels of LH and FSH in maturing rats: response to hemigonadectomy. Endocrinology $90,466-472$.

Pedersen, T. (1969) Follicle growth in the immature mouse ovary. Acta endocr., Copenh. 62, 117-132.

Pedersen, T. (1970) Cell population kinetics of the ovary of the immature mouse after FSH stimulation. In Gonadotrophins and Ovarian Development, pp. 312-324. Eds W. R. Butt, A. C. Crooke \& M. Ryle. E. \& S. Livingstone, Edinburgh.

Pedersen, T. \& Peters, H. (1968) Proposal for a classification of oocytes and follicles in the mouse ovary. $J$. Reprod. Fert. 17, 555-557.

Ryle, M., Kent, J. \& Boggis, J. (1973) Hormone effects in vitro on follicle growth in infantile mouse ovaries. In The Development and Maturation of the Ovary and its Functions, pp. 29-37. Ed. H. Peters. Excerpta Medica, Amsterdam.

Uilenbroek, J.T.J., Arendsen de Wolff-Exalto, E. \& Welschen, R. (1976) Studies on the significance of the high levels of follicle stimulating hormone for follicular development in immature rats. Annls Biol. anim. Biochim. Biophys. 16, 297-305. 